\title{
Slow-onset disaster and sustainable livelihoods: the Vaal River in the vicinity of Parys
}

\author{
G VAN RIET AND JWN TEMPELHOFF*
}

\begin{abstract}
This article is based on data gathered during a research project commissioned by the Fezile Dabi District Municipality in the northern part of South Africa's Free State Province. The research team (which included the authors) was asked to investigate allegations of pollution of tap water, as well as sewage from the local wastewater treatment plant flowing into the Vaal River in the town of Parys on the banks of the Vaal River. The authors adopt a sustainable livelihoods approach in analysing data gathered by way of unstructured interviews in and around Parys in June-July 2008. They argue that actual and perceived levels of pollution are eroding various local livelihood assets and it is posited that the situation constitutes an unfolding slow-onset disaster. It is imperative that shocks such as sewerage spills and rumours of polluted potable water are addressed to ensure that these do not become long-term negative trends.
\end{abstract}

Keywords: Water service delivery, Ngwathe Local Municipality, wastewater treatment, potable water supplies, Vredefort Dome World Heritage Site, Vaal River, Barrage, sustainable livelihoods, slow-onset disaster, fishing, farming, tourism.

Disciplines: Disaster studies, history, integrated water resource management, environmental studies.

\section{Introduction}

In 2008, media reports gave currency to rumours of an environmental crisis in the Northern Free State town of Parys in South Africa. All was reportedly not well with the town's water. ${ }^{1}$ There was an atmosphere of acrimony between residents and the management of Ngwathe Local Municipality about the condition of the local potable water supply and the fact that the town's raw sewage flowed directly into the Vaal River that meanders through Parys. Residents claimed that the town's water

* Gideon van Riet is attached to the African Centre for Disaster Studies at NorthWest University's Potchefstroom campus. Johann Tempelhoff is head of NWU's Research Niche Area for the Cultural Dynamics of Water at the Vaal Triangle Campus in Vanderbijlpark.

1 R Myburg, "Vaalrivier se water gevaarlik sê kundige" in Die Noord-Vrystaatse Gazette, 2008.03.06, p. 3; Anon., "Regering gaan help om rioolbesoedeling in Vaal reg te stel" in Die Noord-Vrystaatse Gazette, 2008.03.13, p. 5; R Myburg, "Vaal se besoedeling beskryf as 'n nasionale krisis" in Die Noord-Vrystaatse Gazette, 2008.03.27, p. 5; Anon., "Protesoptog teen waterbesoedeling: inwoners oorhandig memorandum" in Die Noord-Vrystaatse Gazette, 2008.04.03, p. 5. 
infrastructure was not being managed properly. The local authority's management, in turn, tended to ignore what it considered to be false allegations.

Contemporary circumstantial evidence gave the benefit of the doubt to the residents. Many local authorities in the rural parts of South Africa have for some time been faced with similar problems in the broad field of service delivery. Recent research suggests that the potable water supplies, especially in small urban settlements, are below acceptable standards. ${ }^{2}$ General discontent with service delivery in other parts of the country has, for some time, given rise to violent confrontations between residents and local municipal officials. ${ }^{3}$ In response to a state of affairs that experts ascribe to rapid development, unprecedented urbanisation and a severe shortage of sufficient skills, ${ }^{4}$ residents of urban settlements in the rural regions have stopped paying rates and taxes to local authorities. They then take the responsibility of securing certain essential services for themselves. These arrangements usually mean that local authorities experience a loss of revenue from rates and taxes. ${ }^{5}$ Furthermore their credibility and standing in the broader civil society takes a knock.

2 C Nothnagel, K Kotte, JJ Pienaar, PG van Zyl and JP Beukes, "Disinfection byproducts and extractable organic compounds in South African tap water" in The Journal for Transdisciplinary Research in Southern Africa, 4(1), July 2008, pp. 175-180.

3 M Hough, "Violent protest at local government level in South Africa: revolutionary potential?" in Scientia Militaria, 36(1), 2008, p. 8.

4 Sapa, "Infrastructure maintenance getting attention" in $I O L, 2008.05 .21$ at http://www.iol.co.za/

index.php?set id=18click id=3045\&art id=nw20080521132608605C650979; A Powell, "Shock finding on Cape water" in Cape Times, 2008.03.04 at http://www.iol.co.za/ index.php? set $i d=1 \& c l i c k$ id $=3045 \&$ art $i d=v n 20080304060439991$ C659539 (accessed 2008.09.09); Sapa “'Transkei infrastructre collapsing" in IOL, 2008.01.10. at http://www.iol.co.za/

index.php? set $\mathrm{id}=18 \mathrm{click} \mathrm{id}=30458 \mathrm{art} \mathrm{id}=\mathrm{nw} 20080110182101694 \mathrm{C} 303029$ (Accessed 2008.09.09).

5 C Visser, "So pak Sannieshof dienstekrisis" in Beeld, 2008.07 .02 at http://152. $111.1 .251 /$ argief/berigte/beeld/2008/07/02/B1/16/brief.html (Accessed 2008.09.25); Also see JWN Tempelhoff, "Service delivery conflict in South Africa's water sector: Phiri, Soweto's pre-paid meter protest" in Quarterly Bulletin of Third World Studies, 49(1), 2009, pp. 30-53. 


\section{Figure 1 Map of Parys in the Northern Free State, Potchefstroom North West Province and the south-western parts of Gauteng. ${ }^{6}$}

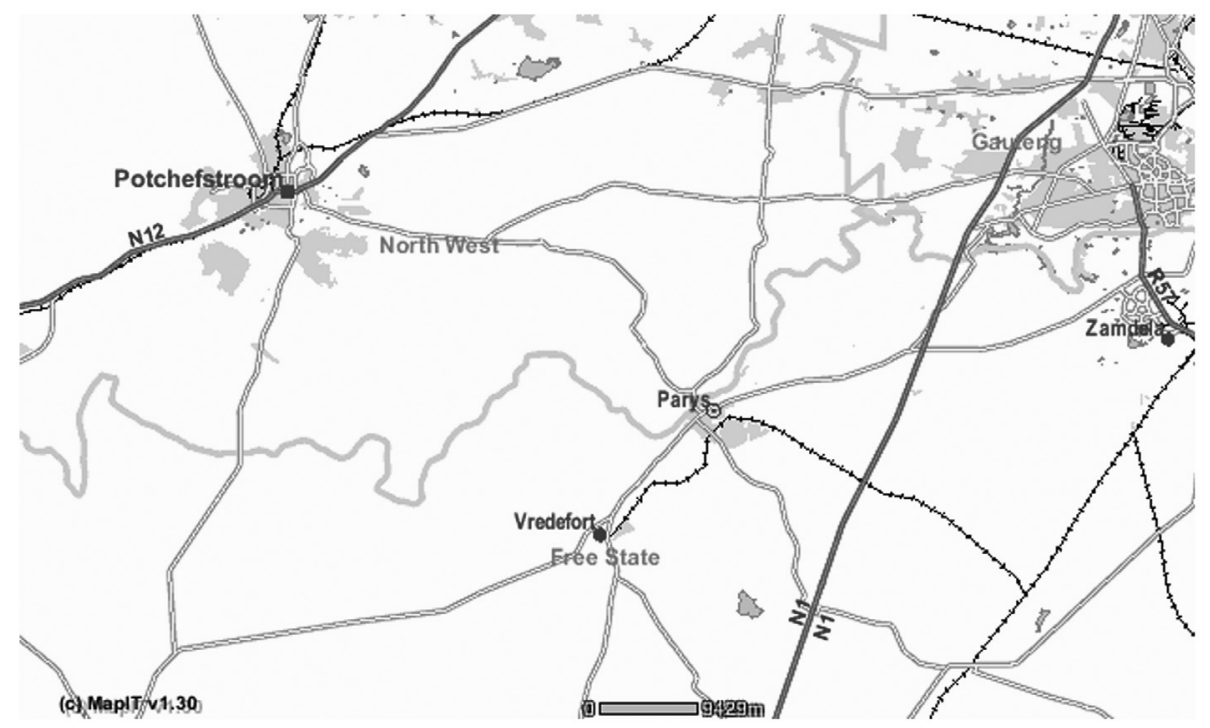

In an effort to proactively address the apparent inability to defuse the problem of Parys' water, the council of Fezile Dabi District Municipality, of which Ngwathe Local Municipality forms part, opted for an independent assessment of the state of affairs. Members of North-West University's Research Niche Area for the Cultural Dynamics of Water were then appointed to conduct the relevant research. Working in a transdisciplinary research framework and in collaboration with representatives of all stakeholders in the community, the team came to the conclusion that there were indeed problems. While the town's potable water supply appeared to be in a satisfactory condition, raw sewage from the local wastewater treatment works flowed freely into the Vaal River. ${ }^{7}$ This had a marked effect on the environmental health of the river which meanders through the Vredefort Dome, a listed UNESCO World Heritage site.

Working from data captured during fieldwork, ${ }^{8}$ it was possible to classify the water situation of Parys as a typical slow-onset disaster. The ramifications of this state of affairs became evident when attention was given to the manner in which water pollution in the Vaal River affected the sustainable livelihoods of local economically active stakeholders who have high levels of dependency on the river and its immediate environment.

6 Source Easymap.co.za (Accessed 2008.09.04).

7 JWN Tempelhoff, A van Zyl, G van Riet, C Gouws, J Hardy, H Jordaan, A Ludick, S Motloung, A Schlemmer, A Venter, G van Geuning and H van Wyk, "An investigation into the environmental health of the Vaal River in the vicinity of Parys" (Report 1/2008. Research Niche Area for the Cultural Dynamics of Water, North-West University Vaal, Vanderbijlpark, 2008).

8

Ibid. 
By taking into consideration public perceptions on the quality of water, as well as the factual state of affairs, a number of recommendations were made to the authorities. One was that a local forum be established in which all stakeholders would have the opportunity to consider constructive plans for solving the local water problems.

\section{Outline}

In the discussion to follow attention is given to an exposition of the transdisciplinary methodological strategies followed in the execution of the project. A brief historical sketch is given on Parys and the Vaal River and it is shown that apart from providing the town with its potable water supply, the river is also responsible for the community's environmental dignity. Attention then focuses on the dissatisfaction of the local residents with Ngwathe Local Municipality's service delivery in the water sector and how residents linked up with the non-governmental organisation Save our Vaal Environment (SAVE), operating in the Vaal River Barrage area.

After providing some theoretical underpinnings of a slow-onset disaster scenario, there follows an exposition of the concept of a sustainable livelihoods framework approach to interpreting the water situation. This then leads to an analysis of empirical research data collected in Parys. The focus is specifically on the impact of poor water quality on the local tourist industry, the farming sector and the informal professional fishing community. Finally follows a short discussion on recent steps taken by the local authority and civil society.

\section{Research planning and project execution}

Research on the water problems at Parys began in March 2008. A number of meetings were held with members of the Research Niche for the Cultural Dynamics of Water at NWU's Vaal Triangle Campus and a senior official of environmental health at the Fezile Dabi District Municipality. Subsequent meetings were also convened with some members of civil society in the vicinity of Parys and the Vredefort Dome. Later a selected group of stakeholders, representative of urban and peri-urban property owners; the local tourist industry; local business; municipal officials; and representatives of a University of Johannesburg research team working on fish in the Vaal River below the Barrage, were invited to participate in talks aimed at locating essential aspects of the problem. This comprehensive meeting took place on a smallholding, Somerplaas, on the outskirts of Parys. The understanding was that transdisciplinary strategies would be pursued in executing the project. While some participants had accredited proficiency in water studies, environmental studies, disaster management and tourism studies, there was also specialised knowledge in the academic fields of history, political science, public management, zoology and botany. Notwithstanding this, the understanding was that representatives of local stakeholders would also form part of the team. By participating as co-researchers and co-authors of the project, the non-academic participants were well-positioned to communicate in the heuristic process, providing valuable local knowledge and a realistic understanding of human interaction with the Vaal River environment that borders on the Northern Free State and part of the 
North West Province.

In the first week of June 2008 a research group of 12 participants met at Parys to undertake fieldwork. In the course of five days almost 50 group and individual interviews were conducted with a broad spectrum of people. Respondents included urban dwellers in the residential townships of Parys, Tumahole, Vredefort and Mokwallo. Farmers and operators of private tourism facilities along the Vaal River were also consulted. Furthermore, a random series of interviews and informal discussions were held with local business people. Here the most important imperative was to determine the precise extent to which respondents interacted with the Vaal River environment and relied on the river for their livelihood.

In July, individual members of the research team shared their findings at a one-day internal conference. Then a first draft of the report was compiled and circulated among members. After electronic correspondence a second version of the report was prepared. Stakeholders in the public realm were then, in August, invited to a meeting where the report was discussed. Preliminary copies of the report were distributed before the time, as well as at the meeting which was attended by about 40 people. Subsequently, the report was edited and adjusted in response to comments and recommendations made at the meeting. In November 2008 the final report was submitted to Fezile Dabi District Municipality, whose council later approved it.

Throughout the research and writing process there was a concerted effort to empower stakeholder participation. All members were able to participate as equals in the collection of information and group discussion. There were frequent debriefing sessions to consolidate perceptions and summarise essential preliminary findings. Although not all stakeholders responded with equal fervour, the opportunities were there for them to make meaningful contributions. In the process they were also in a position to gain a more comprehensive perspective of the water problems in the region.

The contribution of stakeholder participants, specifically the sharing of local knowledge with members of the team, enhanced the quality of the team's understanding of the local culture. Broad-based participation in the project also served other purposes. Apart from seeking transparency, the objective was to make the complex issues of water management and administration user-friendly to the general public. This was seen as one way of giving recognition and significant status to 'ordinary' people of the area and an indication that their views were indeed respected. In the process an awareness was cultivated of how valuable the river and its water are to the town and its surroundings. This basic affirmation of aquatic space enhanced the comprehension of what the environmental health of the Vaal River means to all stakeholders.

The theoretical thrust of the report focused on disaster risk reduction. For the members of the research group it was abundantly clear that the report outlined a worthwhile route to follow in the search for a solution to Parys' water problems. One of the initial foci was to look at issues of disaster management. The idea was mooted that if critical problems of urban water supply were categorised as a disaster situation, there would be a more immediate response to similar predicaments faced by civil 
society in other parts of South Africa. Working from a slow-onset disaster situation, the researchers then tried to contextualise its impact on sustainable local livelihoods in Parys. This process is discussed below.

\section{Historical background to the condition of Parys' water}

Early in the investigation it became evident that the water problems of Parys (founded in 1876) ${ }^{9}$ had its origins in the early twentieth century when construction work began in 1915 on the Barrage at Lindequesdrift, upstream in the Vaal River. ${ }^{10}$ Although the Barrage, a storage facility of the utility Rand Water (formerly the Rand Water Board), secured a more consistent water supply for Parys, especially during the dry winter months, it was responsible for many other problems. Rapid urbanisation and the more intensive consumption of the Vaal River's water for industrial purposes had the effect that the quality of the water flowing down the Vaal from the Barrage, deteriorated markedly. Some examples prove the point. Coal mining operations in the Vaal Triangle began in the 1880 s. From the 1910 s onwards a number of coal-fired power stations in the Vereeniging area caused the quality of the water to decline. The operations of the Union Steel Corporation (founded in 1911) were also responsible for contaminating the Vaal River in the Barrage area. ${ }^{11}$ By the 1930s dilution strategies that involved passing water into the Barrage from the newly completed Vaal Dam, appeared to reduce the problem of deteriorating water quality. However, as South Africa's industrial development gained momentum, ${ }^{12}$ the Vaal Triangle became a hive of industrial activity. At the town of Vanderbijlpark (founded in 1944) South Africa's Iron and Steel Corporation (ISCOR) established a large flat-steel foundry. On the Free State side of the Vaal River, Sasolburg was founded in 1950 and became the hometown of the country's first petroleum from coal manufacturing plant by another parastatal, SASOL. ${ }^{13}$

Oral information collected during fieldwork in June 2008, suggests that residents of Parys became aware of the unsatisfactory water quality in

9 JH Van Eeden, Parys 1876-1976: die geskiedenis van Parys (Parys? Munisipale Raad van Parys, c. 1976); AG Oberholster, "Parys on the Vaal" in Contree, 3, January 1978, pp. 10-15.

10 C Gouws, J Hardy, H Jordaan, A Ludick, S Motloung, A Schlemmer, JWN Tempelhoff (team leader), G van Riet, A Venter, and G van Greuning, H van Wyk and A van Zyl (assistant team leader), "An investigation into the environmental health of the Vaal River in the vicinity of Parys" (Third draft report, Water Niche Area for the Cultural Dynamics of Water, North-West University, Vaal Triangle Campus, Vanderbijlpark 23 September 2008), p. 9.

$11 \mathrm{CW}$ Guest, "Die ontwikkelingsgeskiedenis van die Unie-staalkorporasie, 19111996" (MA, PU for CHO, Vanderbijlpark, 1999).

12 GE Schneider, "The development of the manufacturing sector in South Africa" in Journal of Economic Issues, 34(2), June 2000, pp. 413-424, (especially p.417).

13 See JWN Tempelhoff, "Water and the human culture of appropriation: the Vaal River up to 1956" in TD The Journal for Transdisciplinary Research in Southern Africa, 2(2), December 2006, pp. 431-452. 
the 1940s. ${ }^{14}$ The town's official history confirms this. In 1941 Rand Water declined to respond favourably to a request by the town fathers that Parys be linked to the Rand Water supply network. However, the water utility was prepared to put in a good word for Parys at government level and the authorities responded by making funds available for the construction of Parys' first water purification works. ${ }^{15}$

Parys had always relied on the Vaal River for its drinking water. The town also used the river for other purposes. Part of its wastewater was allowed to flow into the river downstream of the residential area. In a responsible manner, processed sewage from the town's wastewater treatment works flowed downstream in the river and seldom compromised the environmental dignity of local residents. Since the 1990s, as a result of the transition of governance structures to a multiracial democratic dispensation, the quality of the town's water, according to residents, began to deteriorate. Increasingly there were concerns that this was because of persistent upstream sewage spills in the region of the Vaal Triangle specifically in the Vaal River Barrage storage area. ${ }^{16}$

Residents interviewed in June 2008 complained that Parys' water had a rotten smell, ${ }^{17}$ showed visible traces of algae, ${ }^{18}$ and tasted strange. This had been going on for a considerable period of time. Numerous examples were cited of people, especially children, suffering from diarrhoea. ${ }^{19}$ Although there was reason to believe that the water purification plant had been operating poorly prior to June 2008, the research team was assured that the plant was being serviced and brought up to full operational standards. Unscheduled spot checks by environmental health officials of the Fezile Dabi District Municipality and members of the research team confirmed that officials of the local municipality and contractors were in the process of doing upgrading and maintenance work.

Claims to the effect that raw sewage from the Parys wastewater treatment works flowed into the Vaal River adjacent to the centre of town were indeed accurate. At the beginning of June 2008 the plant was not in proper running order. ${ }^{20}$ It was found that the deteriorating state of affairs

14 G van Riet, interview Anonymous, Tumahole, 2008.06.03.

15 JH van Eeden, Parys 1876-1976 (Munisipale Raad van Parys, Parys?, 1976), 62.

16 JWN Tempelhoff, "Civil society and sanitation hydropolitics: a case study of South Africa's Vaal River Barrage" in Physics and Chemistry of the Earth, Parts A/ $B / C, 34(3), 2009$, pp. 164-175.

17 H Jordaan, interview Motsoko, 2008.06.02; C Gouws, interview Ms G Van Der Merwe, 2008.06.02; Photographic evidence: JWN Tempelhoff, 2008.06.06.

$18 \mathrm{C}$ Gouws, interview Ms L van den Berg, Ms G van der Merwe, 2008.06.02.19 JWN Tempelhoff and S Motloung, interview (Percy) Boy Moloi Ramahodi(56), Principal Ntshewephepa Primary School, Lusaka Extension, Tumahole Township, Parys, 2008.06.04.

20 C Gouws, J Hardy, H Jordaan, A Ludick, S Motloung, A Schlemmer, JWN Tempelhoff (team leader), G van Riet, A Venter, and G van Greuning, H van Wyk and A van Zyl (assistant team leader), "An investigation into the environmental health of the Vaal River in the vicinity of Parys" (Third draft report, Water Niche Area for the Cultural Dynamics of Water, North-West University, Vaal Triangle Campus, Vanderbijlpark 23 September 2008), pp. 26-7. 
was as a result of poor maintenance of infrastructure. ${ }^{21}$ The management of Ngwathe Local Municipality assured the members of the research team that the matter was receiving urgent attention and that officials were working in collaboration with the department of water affairs and forestry (DWAF). ${ }^{22}$

Because of their grave concerns about the deterioration of the town's water, in 2007 some Parys residents began to cast around for some form of external moral support. It was then that they started communicating with the non-governmental organisation (NGO) Save our Vaal Environment (SAVE) that has been operating in the Barrage area since the mid-1990s. As of 2003 the NGO has concentrated on local sewage pollution in the Barrage. In the space of a short time SAVE's management effectively negotiated with the management of Emfuleni Local Municipality, ${ }^{23}$ the department of water and environmental affairs, as well as with senior political role players on provincial and national government level. ${ }^{24}$ Government began to take note of the efforts of civil society in the Vaal River Barrage area. ${ }^{25}$ All this met with the approval of the residents of Parys. Their representatives then began attending SAVE meetings. One local activist, Edward Mafereka, took the initiative to establish an NGO called Sciento Cultural Occult Paragenetic Evolution Research (Scoper). This group aligned itself closely to SAVE. In March

$21 \mathrm{H}$ Jordaan, C Gouws, A Venter, J Tempelhoff and S Motloung, interim reports to members of the research group.

22 At the time of the fieldwork excursion in June 2008, members of the research team met informally with officials of the department of water affairs and forestry (DWAF), who were conducting tests and taking samples at the Parys wastewater treatment works.

23 The local authority, through Metsi-a-Lekoa, a non-profit enterprise, is responsible for the management of the water infrastructure in Vanderbijlpark and Vereeniging.

24 JWN Tempelhoff, V Munnik and M Viljoen, "The Vaal River Barrage, South Africa's hardest working waterway: a historical contemplation" in TD The Journal for Transdisciplinary Research in Southern Africa, 3(1), July 2007, pp.107-133; CM Gouws, C Gouws, R Mathipa, K Motumi, JWN Tempelhoff, and $\mathrm{M}$ Viljoen, "Perspectives on Emfuleni's aquatic commons: a qualitative study on the Vaal River Barrage", Report 3/2007 (North-West University, Vaal Triangle Campus, Released 2007.09.19); For the most recent implications of the spills see JWN Tempelhoff, "The fish-kills and clean-up operations $\mathrm{n}$ the Vaal River Barrage" November 2008-April 2009 (Report for Messrs JT Industrial Waste Management, Vanderbijlpark, April 2009).

25 More recently SAVE resorted to taking legal steps in an effort to bring to an end the persistent problem of sewage pollution in the Vaal River Barrage. See the following documentation: The High Court of South Africa (Witwatersrand local division): Case 08/400064, The matter between SAVE and the Emfuleni Local Municipality, 2008.11.21; The High Court of South Africa (Witwatersrand local division): Case 08/41554, The matter between SAVE and the Emfuleni Local Municipality, 2008.12.05; The High Court of South Africa (Witwatersrand local division): Case 08/400064, The matter between SAVE and the Emfuleni Local Municipality, 2008.12.05. Also see E Tempelhoff, "Hof gelas herstel van pompstasies: organisasie keelvol vir riool" in Beeld, 2008.11.24 at http:// 152.111.1.88/argief/berigte/volksblad/2008/11/24/VB/4/etsave 1936.html (Accessed 2009.04.04). 
2008 a representative of SAVE staged a march, together with Scoper supporters, to hand over a memorandum to the management of Ngwathe Local Municipality. ${ }^{26}$

It was against this backdrop of growing civil discontent that the NWU researchers entered the research area. After investigating the local water quality problem from various perspectives they settled for a slow-onset disaster scenario in the local water sector. In an effort to transmit the implications of this state of affairs in a comprehensible manner, the ramifications of low quality water was contextualised in a local sustainable livelihoods framework (SLF).

\section{Theoretical underpinnings of slow-onset disaster and sustainable livelihoods}

According to the United Nations' International Strategy for Disaster Reduction (UNISDR) a disaster can be defined as:

A serious disruption of the functioning of a community or a society causing widespread human, material, economic or environmental losses which exceed the ability of the affected community or society to cope using its own resources. ${ }^{27}$

A distinction can, however, be made between rapid-onset disasters, such as mudslides and flash floods, which are often difficult to predict and slow-onset disasters, which typically arise over a longer period of time. They may take months, years, or even decades to unfold. Slow-onset disasters such as environmental degradation and drought should typically be easier to address than rapid-onset disasters. In many instances warning signs are evident long before the situation reaches disastrous proportions. However, these signs are often ignored until it is too late for effective preventative or mitigating actions to be taken. ${ }^{28}$

Disasters occur within complex social settings. Various social, economic, political and environmental factors and the interaction between these can contribute to the prevention and mitigation of disasters. ${ }^{29}$ Effective measures begin with a thorough understanding of these dynamics, and to clarify them in the particular study area, the SLF is used.

The SLF, (see Figure 1 below) has in recent years been applied increasingly as a conceptual tool in the field of development. It offers a holistic framework to understand local livelihoods by focusing on various types of local capacities and prevailing conditions, such as seasonal shocks and the ambient political and institutional environment. Thus, by using the SLF, aspects facilitating favourable or unfavourable

26 Anon., "Protesoptog teen waterbesoedeling: inwoners oorhandig memorandum" in Die Noord-Vrystaatse Gazette, 2008.04.03, p. 5.

27 UNISDR, Terminology on Disaster Risk Reduction. (Geneva: United Nations. 2009). www.unisdr.org/eng/terminology/terminology-2009-eng.html (Accessed 2009.05.29).

28 D van Niekerk, Disaster Risk Reduction, (African Centre for Disaster Studies Potchefstroom University for CHE, 2002).

29 B Wisner, P Blaikie, T Cannon, I Davis. At Risk: Natural Hazards, People's Vulnerability and Disasters (London: Routledge, 2004). 
"livelihoods outcomes" can be identified. In 1991 Chambers and Conway first unveiled this tool for the analysis of rural livelihoods. ${ }^{30}$ Other experts have subsequently adopted the framework in the context of urban livelihoods. ${ }^{31}$ According to Chambers and Conway:

A livelihood comprises the capabilities, assets (stores, resources, claims and access) and activities required for a means of living: a livelihood is sustainable which can cope with and recover from stress and shocks, maintain or enhance its capabilities and assets, and provide sustainable livelihood opportunities for the next generation; and which contributes net benefits to other livelihoods at the local and global levels and in the long and short term. ${ }^{32}$

In order to achieve a sustainable livelihood, individuals and households can make use of five types of assets or capacities. Human assets refer to the set of skills (such as ingenuity) an individual may possess. Social assets are those networks and relationships with others which yield personal gain. For example, different households might pool their labour. Trust is of course a significant component of such relations. According to the UK's Department for International Development (DFID), cooperation based on trust may improve people's access to various institutions, such as political and civic bodies. ${ }^{33}$ Physical assets include infrastructure, houses or any potential productive asset. Finally, resources such as fresh water, wood supplies and arable land are valuable natural assets.

Assets acquire specific meanings in their particular political, institutional and cultural environment. According to DFID they form part of the so-called "transforming structures". ${ }^{34}$ These structures also assert an influence on the "vulnerability context". They may present themselves as trends and tendencies, such as demographic shifts, experiences of extraordinary surprise (shock), such as economic crises, and as seasonality in the form, for example, of seasonal job opportunities or the seasonality of prices. The vulnerability context also has an impact on the amount and type of livelihood assets individuals, households and communities may posses. In his discussion of the vulnerability context, de Satge distinguishes between shocks and stresses. ${ }^{35}$ Shocks entail sudden events that erode household assets, such as the death of a breadwinner or a flood. Stresses, on the other hand, are longer term

30 R Chambers and GR Conway, "Sustainable rural livelihoods: practical concepts for the 21st century" (IDS, Discussion Paper 296, 1991).

31 For example, see M Lyons and S Snoxell, "Sustainable urban livelihoods and marketplace social capital: crisis and strategy" in Petty Trade Urban Studies, 42(8),2005, pp. 1301-1320.

32 R Chambers and GR Conway, "Sustainable rural livelihoods: practical concepts for the 21st century"(IDS Discussion Paper 296, 1991), pp. 7-8.

33 Department for International Development, Sustainable Livelihoods Guidance Sheets. 1999. http://www.livelihoods.org/info/info_guidancesheets.html (Accessed February 2008).

34 Ibid.

$35 \mathrm{R}$ de Satge, "Livelihoods analysis and the challenges of post-conflict reocovery" in J Clover and R Cornwell (eds.), Supporting Sustainable Livelihoods: A Critical Review of Assistance in Post-conflict Situations, Monograph 102 (Pretoria: Institute for Security Studies), August 2004, p. 39. 
"trends" (see Figure 1 below), which may undermine livelihoods. Examples include aspects such as environmental degradation and climate change. ${ }^{36}$

The SLF does not merely offer a one way, structuralist explanation whereby local communities are rendered helpless in the wake of prevailing political, economic and environmental processes. The utilisation of livelihoods assets can also positively or negatively impact on the vulnerability context and the transforming structures.

\section{Figure 1: The sustainable livelihoods framework (SLF). ${ }^{37}$}

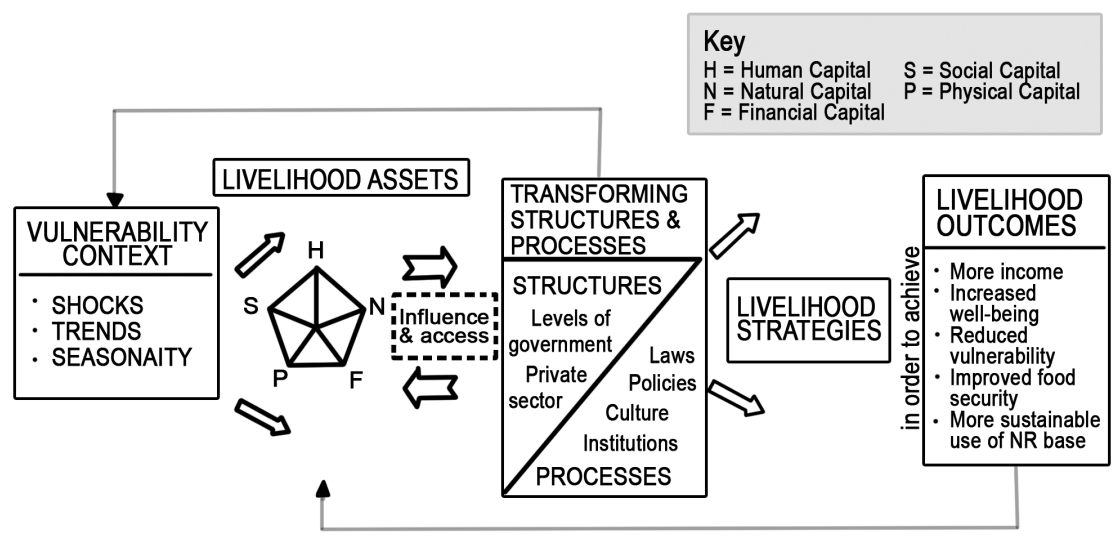

It is evident that shocks, such as water pollution induced by human action/inaction in the study area, negatively impact on the livelihoods assets, of local communities. If these shocks continue over time and become negative trends, the situation in Parys could well be one of a slow-onset disaster.

\section{The Vaal River and local livelihoods}

It seems clear that various local livelihoods are to a varying extent dependent on the Vaal River. In many instances this relates to riverbased tourism activities. These range from adventure tourism initiatives, to fishermen and fishing equipment retailers, to numerous other retailers and service providers who benefit indirectly from the tourism industry. Small-scale commercial fishing also takes place. Farmers are largely dependent on the river for their livelihoods, because their irrigation systems draw on the river.

\section{Tourism industry}

Since the Vredefort Dome was listed in 2005 on UNESCO's list of

36 Ibid., p. 40.

37 Department for International Development, Sustainable Livelihoods Guidance Sheets. 1999. http://www.livelihoods.org/info/info guidancesheets.html (Accessed February 2008). 
prospective World Heritage sites, there has been a boom in the local tourism industry. ${ }^{38}$ Apart from a steady stream of weekend visitors from Gauteng, there is a constant flow of international visitors visiting the region, either individually, or as part of organised tours. Many visitors return to purchase their own holiday homes, while others acquire farms; some even start businesses aimed at providing commercial goods and services in a region where there is considerable demand for leisure time pursuits. ${ }^{39}$ The river plays an important role in almost all the local leisure activities. Of particular importance is adventure tourism, such as river rafting, canoeing, fishing and swimming. ${ }^{40}$ Local resorts are also renowned for corporate breakaways and teambuilding programmes. ${ }^{41}$ The river, which flows through the potential world heritage site, is thus an extremely important natural asset to local livelihoods. It is also important for the urban economy of Parys.

Tourism operators are unanimous that negative reports in the media about the dubious quality of the river water are bad for business. Some feel that no news should be disseminated at all, even when there are indications of an impending environmental crisis. ${ }^{42}$ This attitude is understandable. The tourism industry is an important source of income for many local residents. Apart from the water-based activities mentioned above, there are numerous other forms of outdoor pursuits, such as hiking, bird watching and fishing that are enjoyed along the river banks. In most cases these ventures offer local employment opportunities and are a means of securing financial independence for many households. ${ }^{43}$

The recreational fishing industry, often comprising fishermen who visit tourism venues beside the river, seems to have suffered significant losses in recent years. Many interviewees noted that fishermen complain about the quality and quantity of fish in the river ${ }^{44}$ and mention that the amount of fish caught in a given period of time has declined markedly. ${ }^{45}$ Some claim that the fish are now a different colour, and that some recreational fishermen have even stopped fishing in the area. As the owner of a local fishing supply store noted, many "serious" fishermen now prefer to go to Vaal Dam or Koppies Dam. ${ }^{46}$ This may however, not be

38 The Vredefort Dome is the world's oldest and largest remaining meteorite impact crater. It is located to the west of Parys and north of Vredefort. The dome spans two provinces, the Free State and the North West Province.

$39 \mathrm{~J}$ Tempelhoff, interview S de Jager (56), Somerplaas, 2008.06.02.

40 G van Riet, interview Hannes Pretorius, Vredefort Dome, 2008.06.02; G van Riet, interview Mark Rensleigh, Parys, 2008.06.05.

$41 \mathrm{~J}$ Tempelhoff, interview H Pretorius (54), Dimalachite, 2008.06.02.

42 One interviewee ( $G$ van Riet, interview Hannes Pretorius, Vredefort Dome, 2008.06.02) noted that: "Berigte moet ook sê wat word aan die probleem gedoen". (Reports should also state what is being done [to improve the quality of the water]).

43 All tourism industry operators employ and train local residents.

44 For example G van Riet, interview Eddy Woods, Parys, 2008.06.05; G van Riet, interview Hannes Pretrius, Vredefort Dome, 2008.06.02.

45 An owner of a fishing supplies store in Parys (G van Riet, interview Vicki van Vuuren, Parys, 2008.06.02) noted that about 10 years ago, it was possible to catch about 20 yellowfish in four hours in the Vaal River. Now fishermen typically only catch two or three.

46 G van Riet, interview Vicki van Vuuren, Parys, 2008.06.02. 
entirely due to the alleged pollution. One explanation offered is that new golf estate developments are chasing the fish away because of the constant noise pollution. ${ }^{47}$ Fishermen may also be less likely to visit Parys as a result of the current economic climate in the country. Media reports on the economy indicate that the country's consumers currently spend less on retail goods and services. ${ }^{48}$ One of the tourists also complained about the smell of the water. ${ }^{49}$

At some resorts where non-water based activities are offered, and visitors do not directly come into contact with the river, the water problem is less severe. Activities, such as quad-biking, mountain biking, hiking, hunting and game viewing, for example, are not as dependent on the quality of river water. However, one should not overlook the fact that at times the situation becomes very serious. On one occasion a tourist was hospitalised after drinking water from the river. ${ }^{50}$ At the beginning of 2008 there were indications of staff cutbacks at tourism resorts because of the deteriorating condition of the river's water. This meant that in addition to the economic downswing that South Africa has experienced since 2007, the local economy was dealt an even harsher blow. ${ }^{51}$ According to operators in the tourism sector there has been an increase in local job losses.

The power of media reports is worth noting. After negative press reports, those in the tourism industry claimed that potential tourists had cancelled their reservations. ${ }^{52}$ Given the delicate nature of this situation, the need for a balance between two important issues should be considered. On the one hand, the safety of tourists should not be jeopardised in any way; this is non-negotiable. On the other hand, policy recommendations and especially media reports should not be exaggerated. These reports should be written from a perspective which is (at least to some extent) sensitive to the needs of the tourism industry, without compromising the safety of anyone concerned.

As reports of water pollution and evidence thereof accumulate over time the potential impact on water-based tourism activities is clear. As a significant natural asset the state and perceived state of the Vaal River is of crucial concern to many working (either directly or indirectly) in the tourism industry in the area.

\section{Farming}

Farming is arguably the most significant economic activity in the Vredefort Dome area immediately downstream from Parys and for this industry the river is a crucial natural asset. From the data gathered it seems that this sector has indeed been negatively affected by pollution. According to interviewees, water pollution has affected the type of

47 Ibid.

48 Anon., "Retail sales take steepest dive in 9 years" in Business Day, 2008.07.17, pp. 1 and 2.

49 G van Riet, interview Johan Bester, Parys, 2008.06.02.

$50 \mathrm{G}$ van Greuning, interview Anonymous, 2008.06.06.

51 Anon., "Regering gaan help om rioolbesoedeling in Vaal reg te stel" in Die NoordVrystaatse Gazette, 2008.03.13, p. 5.

52 H Jordaan, interview PG Schoeman, Vredefort Dome, 2008.06.06. 
agricultural activities practised; it has also meant that farmers have incurred additional expense.

Using water from the Vaal for irrigation has proved problematic. Tobacco production was previously quite extensive in the Vredefort Dome area. ${ }^{53}$ This crop had to be discontinued because it was rejected at the market due its high chlorine content. The suspicion is that this originated from the Parys sewerage plant. ${ }^{4}$ Similarly, vegetable production, another relatively lucrative pursuit was also stopped when produce was rejected at the market and farmers were told that their vegetables smelt of sewage. ${ }^{55}$ One respondent claimed that due to the presence of heavy metals in the water: "if you irrigate, your land is polluted". ${ }^{56}$ Farmers also complained about the quality of the products when using water from the Vaal for irrigation purposes. One farmer who grew wheat attested that he obtained two tonnes per hectare less than usual when he used Vaal water. ${ }^{57}$

As for farming with livestock, it was claimed that there were cases of cattle in the area dying and that a veterinarian had put this down to drinking polluted water. ${ }^{58}$ It was also alleged that widgets had become more prevalent compared to previous years. These insects eat at the teats of cattle and carry horse diseases. ${ }^{59}$ Other reports indicate that there seem to be more weeds in the area than previously and this is costly because sheep farmers have to hire additional labour to clean the wool.

All these problems are potentially compounded by the fact that fresh water in the Vredefort Dome area is a relatively scarce commodity. The ground water level and water pressure are both very low, ${ }^{60}$ and there are also reports of certain streams drying up. ${ }^{61}$ Furthermore, it has been reported that some of the ground water has been polluted. Local residents also feel there is a difference between water from boreholes closer to the river, compared to water from boreholes further away. ${ }^{62}$

A game farmer who relies on the river for tourism complained about the

53 In one interview ( $\mathrm{G}$ van Riet, interview A Kotze, WR Deadwith and M Prinsloo, Kommandonek, 2008.06.03) it was mentioned that tobacco produced in the Vredefort Dome area used to be of such a quality that it won awards, beating highly regarded 'Rhodesian' (Zimbabwean) tobacco. It was also revealed that there used to be a cooperative in Parys servicing the tobacco industry, which subsequently had to close down.

54 G van Riet, interview Louwtjie van Rensburg, Vredefort Dome, 2008.06.02.55 G van Riet, interview Herman van Wyk, Vredefort Dome, 2008.06.05.

56 G van Riet, interview Pretorius, Vredefort Dome, 2008.06.03.

57 G van Riet, interview Kotze, Deadwith and Prinsloo, Kommandonek, 2008.06.03.

58 G van Riet, interview Van Rensburg, Vredefort Dome, 2008.06.04.

59 G van Riet, interview Kotze, Deadwith, Prinsloo, Kommandonek, 2008.06.03; G van Riet, interview Pretorius, Vredefort Dome, 2008.06.03.

60 G van Riet, interview Johannes van der Merwe, Tabella Thabeng, 2008.06.03.

$61 \mathrm{G}$ van Riet, interview F de Villiers, Venterskroon, 2008.06.04.

62 One interviewee ( $G$ van Riet, interview Herman van Wyk, Vredefort Dome, 2008.06.05) mentioned that the boreholes on his farm had a high TDS. Those further away have a TDS of about 100. Those within about 50 metres of the river have a count of 600-700. He also said that this water can no longer be used for drinking and that this difference between water quality of boreholes close to and further away from the river, is presumably due to pollution. 
large local private holiday resorts that he says dump their sewage in the Vaal River. Some of these resorts cater for almost 800 visitors a day. He was concerned that their wastewater systems might be unable to cope with vast quantities of sewage, and pointed out that sewage leaks into the river were inevitable. He was also concerned about the bad smell near the river, caused by the Parys sewerage works. ${ }^{63}$

A local nursery operator, resident about $40 \mathrm{~km}$ from Parys, told the research team that at one point he had envisaged moving his business from Pretoria to a farm on the Vaal River. However, because of the quality of the river water he had decided against this. In 1994 he tested the water over a period of time and found significant fluctuations in its quality. According to him the $\mathrm{pH}$ varied between 2.7 and 9.61 ; this made it impossible for him to move his business to the banks of the Vaal. ${ }^{64}$

\section{Fishing}

Many people fish in the Vaal River. These fish are either sold or consumed by the fishermen and their families. People in previously disadvantaged communities have increasingly taken to fishing as a professional pursuit. Some local residents resort to fishing on days when they have no employment as gardeners or casual workers in town. ${ }^{65}$

For many families in Tumahole, red meat is prohibitively expensive and they are seldom able to afford poultry. Consequently, fish caught in the river by local fishermen is in high demand. ${ }^{66}$ Fish with an average size of $30 \mathrm{~cm}$ fetch prices of up to R10 each. ${ }^{67}$ Although there is a constant demand fishermen are not always in a position to meet this. They are simply unable to catch enough fish and this perhaps accounts for incidents of illegal netting that have come to the attention of members of the research team. ${ }^{68}$ There are no reports of local people falling ill as a result of the fish they eat.

Interviewees are adamant that the quality and quantity of fish has declined markedly over the years. This has a potential impact on the

63 C Gouws, J Hardy, H Jordaan, A Ludick, S Motloung, A Schlemmer, JWN Tempelhoff (team leader), G van Riet, A Venter, and G van Greuning, H van Wyk and A van Zyl (assistant team leader), "An investigation into the environmental health of the Vaal River in the vicinity of Parys" (Third draft report, Water Niche Area for the Cultural Dynamics of Water, North-West University, Vaal Triangle Campus, Vanderbijlpark 23 September 2008), p 17.

64 Ibid.

65 S Motloung, interview fisherman, riverfront Parys, 2008.06.04.

66 JWN Tempelhoff and S Motloung, interview Rebecca Modikwe (54), Evelyn Leboko (21), Alina Uhlangs (65), Mabel Beba (50), Anna Nocanda (50), Evelyn Makate (28), Miriam Mokoena (43), House 60, Lusaka Extension, Tumahole Township, 2008.06.04. One of the above interviewees stated: "Ons eet nie vleis nie. Ek kry die vleis as die man die vis vang." (We do not eat meat. I get meat when my husband catches fish).

67 JWN Tempelhoff and S Motloung, interview Rebecca Modikwe (54), Evelyn Leboko (21), Alina Uhlangs (65), Mabel Beba (50), Anna Nocanda (50), Evelyn Makate (28), Miriam Mokoena (60) House 60, Lusaka Extension, Tumahole Township, 2008.06.04.

68 C Gouws, interview Y Pienaar, Parys, 2008.06.02. 
livelihood of the fishermen and the diet of those who buy the fish. For these individuals the river is an even more significant livelihoods asset. Whereas certain tourism and agricultural activities might be able to survive under conditions of pollution, a decline of an important natural asset such as fish stocks, has a far greater impact on fishermen and their clients.

The pollution of a key natural asset (water) thus has clear implications for both tourism and agriculture-based livelihoods in the vicinity of the Vaal, leading to sub-optimal livelihood outcomes. In addition it appears to lead to a decline in other important natural assets, namely soil and fish stocks. Farmers who use the Vaal for irrigation have lower yields and professional fisherman struggle to make a decent livelihood. Furthermore, additional costs incurred to remedy the impact on livestock, such as hiring additional staff to clean sheep, erodes the financial assets of farmers. As has been shown, actual and perceived levels of pollution in the Vaal also cause decline in the financial assets accruing to tourism venture operators. Such shocks on the tourism and agriculture industries may in the future be even more significant because these industries offer employment to local residents and the economy of the town of Parys is dominated by the tourism industry.

\section{Water quality}

The issue of public uncertainty about the quality of water in Parys and environs is at the root of the problem. In June 2008, acting on information drawn from its fieldwork, the research team initiated a water sampling project. The main focus was on collecting samples of the micro bacteriological quality of water used for recreational purposes. Samples were taken under the supervision of AS van Zyl, deputy manager of municipal health services, an official employed by the Fezile Dabi District Municipality. ${ }^{69}$ A major objective was to determine the degree of pollution of the Vaal River with sewage (faecal pollution). ${ }^{70}$ The data gathered (on one occasion and not over a period of time) suggests that there was a risk of gastrointestinal effects in the event of full contact (swimming) or intermediate contact (for example waterskiing, canoeing and angling), while partaking of recreational activities in the Vaal River in the study

69 See Appendix 2 of JWN Tempelhoff, A van Zyl, G van Riet, C Gouws, J Hardy, H Jordaan, A Ludick, S Motloung, A Schlemmer, G van Greuning and $\mathrm{H}$ van Wyk, "An investigation into the environmental health of the Vaal River in the vicinity of Parys", p. 38.

70 Republic of South Africa (RSA) Department of water affairs and forestry (DWAF) South African Water Quality Guidelines. Volume 2: Recreational use, Second edition (Pretoria: DWAF, 1996). 
area. ${ }^{71}$ To this should be added the observed aesthetic impact of pollution on the Vaal River. Aspects such as water taste, smell and colour, do indeed influence the perception of risk, and this was noted by many of the interviewees. ${ }^{72}$

Many residents made negative comments on the municipal tap water that they considered to be suspicious; ${ }^{73}$ and it often looked and tasted "vrot" 74 or "muddy". Others noted that the water smelt like fish. ${ }^{75}$ Many interviewees indicated that they frequently suffered from upset stomachs and knew of others who also had the same complaint, particularly children. ${ }^{76}$ According to interviewees living in the settlements close to Parys, some people had even fallen ill and subsequently died. ${ }^{77}$ It seems that there is a distinct lack of trust in local government's ability and willingness to address the situation.

There have in the past been sporadic breaks in the water supply in Tumahole, Schonkenville, Mokwallo and Vredeshoop, and to a lesser extent the residential areas of Vredefort and Parys. This is mainly due to the fact that old asbestos pipes, which have been in use for many years, are prone to fail and are apparently only being replaced when they

71 According to C Gouws, J Hardy, H Jordaan, A Ludick, S Motloung, A Schlemmer, JWN Tempelhoff (team leader), G van Riet, A Venter, G van Greuning, H van Wyk and A van $\mathrm{Zyl}$ (assistant team leader), "An investigation into the environmental health of the Vaal River in the vicinity of Parys" (Third draft. report, Water Niche Area for the Cultural Dynamics of Water, North-West University, Vaal Triangle Campus, Vanderbijlpark 23 September 2008), pp. 29-31, this can be contrasted to non-contact recreation, which encompasses recreation that does not involve direct contact with water, such as picnicking or hiking next to the river. They also state that: "A more stringent approach is necessary where water contact is frequent and relatively extensive, whereas a less stringent approach can be adopted if water contact is infrequent and minimal. The major factors distinguishing high contact activities in this class from full contact recreation are the degree of water contact (full immersion is likely to occur only occasionally and among novices of a water sport), the age of users (water sports such as waterskiing and windsurfing are usually practised by adults rather that by young children) and health status of users (strenuous water sports are generally practised by water users in a fairly good state of health)."

72 G van Riet, interview H van Wyk, Parys, 2008.06.04.

$73 \mathrm{C}$ Gouws, interviews Ms E van der Merwe, Mr. D Olivier and Ms Y Pienaar, Parys, 2008.06.02.

74 "Vrot" is an Afrikaans word for rotten or rotting.

75 C Gouws, interview Ms E van der Merwe, Parys, 2008.06.02.

76 JWN Tempelhoff and S Motloung, interview (Percy) Boy Moloi Ramahodi (56), Principal Ntshewephepa Primary School, Lusaka Extension, Tumahole Township, Parys, 2008.06.04.

77 For example, G van Riet, interview Celena Msibi, Mokwallo, 2008.06.03; G van Riet, interview Samula Matsipi, Tumahole, 2008.06.03; G van Riet, interview "Aida", Tumahole, 2008.06.03 One interviewee (G van Riet, interview "Emily", Tumahole, 2008.06.03) for example noted: "Baie mense raak siek en gaan dood. Kinders gaan ook dood" (Many people fall ill and die.Children also die). 
give trouble. ${ }^{78}$ Then too an insufficient supply of spare pipes is held in reserve to deal with such problems when they arise. ${ }^{79}$

The manner in which residents cope with this perceived poor water quality varies. Most white interviewees noted that they bought bottled water and did not drink tap water. Visitors to the town and local resorts are issued with bottled water, or informed in advance to secure sufficient supplies for drinking purposes. ${ }^{80}$ Residents of Schonkenville, the former coloured township of Parys, noted that they also tended to buy bottled water if they had the money. ${ }^{81}$ However, it came at a considerable cost. ${ }^{82}$ Interviewees remarked that as a rule, they had no other option but to drink tap water. They simply could not afford to buy bottled water. ${ }^{83}$ Some indicated that they would be prepared to pay more in municipal rates, providing the local authority ensured that the supply was of good quality and consistent. ${ }^{84}$

The causal relationship between the (perceived) quality of tap water and the reported illnesses still awaits confirmation. Some interviewees were convinced that bouts of diarrhoea were directly related to the inferior quality of municipal tap water. ${ }^{85}$ It is also possible, however, that such illnesses might be the result of inadequate sanitation. In fact, more than one participant reported that the townships of Mokwallo, near Vredefort and Tumahole, near Parys, are rapidly expanding, while the provision of sanitation has not been able to keep pace with demand. At least one of the participants who reported frequent stomach ailments admitted to still making use of a bucket toilet.

Local residents employ various strategies to deal with the perceived poor water quality. While the wealthier members of the population can afford to buy drinking water, most residents of the study area cannot afford to

78 One former supervisor for the department of technical services (he remains anonymous for the purposes of this discussion) in the Nngwathe Local Municipality noted that: "Pipes in Vredefort are broken. The pipes are old and people don't have water. There is a need for complete replacement of old pipes. This should be done by the department of water affairs."

79 A Venter and A van Zyl, interim reports and disclosures to members of the research group at internal conference 2008.07.14.

80 G van Greuning, interview Steyn, 2008.06.03; G van Greuning, interview Lee, 2008.06.02.

81 For example G van Riet, interview "Cyril", Schonkenville, 2008.06.03; G van Riet, interview Eddie Woods, Parys, 2008.06.05; G van Riet, interview Koos Harmse, Parys, 2008.06.02; G van Riet, interview Johan Bester, Parys, 2008.06.02.

82 JWN Tempelhoff and S Motloung, interview Rebecca Modikwe (54), Evelyn Leboko (21), Alina Uhlangs (65), Mabel Beba (50), Anna Nocanda (50), Evelyn M a k a $\mathrm{e}$ (28), Miriam Mokoena (43), Miriam Mokoena (60), House 60, Lusaka Extension, Tumahole Township, 2008.06.04.

83 G van Riet, interview Celena Msibi, Mokwallo, 2008.06.03; G van Riet, interview "Magdaleen", Tumahole, 2008.06.03.

84 JWN Tempelhoff and S Motloung, interview Rebecca Modikwe (54), Evelyn Leboko (21), Alina Uhlangs (65), Mabel Beba (50), Anna Nocanda (50), Evelyn Makate (28), Miriam Mokoena (43), Miriam Mokoena (60), House 60, Lusaka Extension Tumahole Township, 2008.06.04.

85 H Jordaan, interview J Matsoko, 2008.06.02; H Jordaan, interview A Botes, 2008.06.05; A Schlemmer, interview Botes, 2008.06.03. 
do so. Some residents boil water, before they drink it. Others, if they are aware of the strategy, ${ }^{86}$ add bleach to sanitise their drinking water. However, both these practices, especially the latter are time consuming and expensive. Furthermore, both methods impact on the taste of the water. ${ }^{87}$ Not all those who were interviewed appeared to be familiar with basic strategies to ensure that drinking water is safe.

Statistical analysis of data generated for the Fezile Dabi District Municipality in May 2008, about two months before the transdisciplinary river health research fieldwork was conducted, indicate that the quality of tap water in the town of Parys was in fact well within legal limits for drinking water. Though the water could perhaps, from an aesthetic point of view, appear unclean, the standard of tap water in the area for the purposes of human consumption was in fact very good. This was corroborated by an independent laboratory report on samples taken at the time of the fieldwork in June 2008. ${ }^{88}$

Currently the quality of drinking water in Parys does not seem to be problematic. There is also no concrete evidence that stomach ailments reported by interviewees were indeed the result of poor water quality. However, water may in the past have been below standard, although this is difficult to verify because residents currently perceive perfectly safe water to be of very low quality. This implies that reports of poor water quality in the past, though possibly justified, must be viewed with some scepticism. Stomach disorders can, at least in part, be attributed to questionable sanitation practices. Given the high levels of unemployment and low levels of income in the area, many, if not most local residences cannot afford to buy bottled water. By way of example, quantitative data collected in March 2008 as part of a disaster risk assessment for the Fezile Dabi District Municipality, in Tumhole and Mokwallo, pointed to low levels of income and high levels of unemployment for both settlements. In Tumahole the average combined household income was R1220.00 per month with half of the households earning less than R870.00 per month. In this settlement 27 per cent of households reported at least one member of income earning age (18-60 years) being currently unemployed. ${ }^{89}$ In Mokwallo the average monthly income was R 1306.00, with half the households earning less than R 870.00 per month. In Mokwallo 34 per cent of households reported at least one member of income-earning age being unemployed. ${ }^{90}$

86 JWN Tempelhoff and S Motloung, interview Mr Jeremia Ngandi (51) and Katrina Ngandi (50), House 10930 Mandela Extension, Tumahole Township, Parys, 206.06.04.

87 G van Riet, interview Celena Msibi, Tumahole, 2008.06.03; G van Riet, interview with "Emily", Schonkenville, 2008.06.03;

88 C Gouws, J Hardy, H Jordaan, A Ludick, S Motloung, A Schlemmer, JWN Tempelhoff (team leader), G van Riet, A Venter, and G van Greuning, $H$ van Wyk and A van Zyl (assistant team leader), "An investigation into the environmental health of the Vaal River in the vicinity of Parys" (Third draft report, Water Niche Area for the Cultural Dynamics of Water, North-West University, Vaal Triangle Campus, Vanderbijlpark 23 September 2008).

89 This is defined as currently not involved in paid work (regardless of whether or not the individual is actively seeking employment).

90 G van Riet, C Coetzee, R Musakuzi, and Y Maartens, "Fezile Dabi District Municipality disaster risk assessment: methodology and results" (African Centre for Disaster Studies, North-West University, Potchefstroom, 2008). 
From this it is evident that continuous maintenance of water infrastructure, ensuring a consistent supply of drinkable water, is of the utmost importance. Apart from rendering local populations vulnerable to epidemics, drinking water issues may also compound other crises. They may, for example have a negative impact on the productivity of local residents. Then, along with reported deficiencies in sanitation service delivery, a reduction in the capacity of human resources ensues. It may also affect the local economy at the aggregate level, by for example denigrating the image of Parys as an ideal tourist destination. Cumulative effects might well be difficult to quantify despite their significant negative impact over time. However, managing the quality of tap water and thus limiting negative perceptions is essential to maintain the health of local residents and protect the tourism industry. To the latter end, open lines of communication between local government, the residents and entrepreneurs is essential. This is not only in order that informed decisions be made by local entrepreneurs, and prospective tourists, but also to create much needed trust between key stakeholders, most notably between local government and civil society.

\section{Conclusions and recommendations}

From the discussion above it is evident that at the time of the investigation and the compilation of the research report, there was good reason to believe that conditions were conducive for the development of a slow-onset environmental disaster in the area of Parys and the Vredefort Dome on the banks of the Vaal River. This was confirmed by the local sustainable livelihoods framework compiled by the research team. This state of affairs could typically have a negative impact on the local economy because as an important natural asset, the river makes a significant contribution to local wellbeing. An environmentally sick river compromises not only the livelihood of local residents, but also their aesthetic dignity.

In order to prevent livelihood shocks from becoming negative trends, the research findings suggest that the proper maintenance of water and sanitation infrastructure should become a priority of local government. The purpose of the final report and its findings was not to be part of a whistle-blowing exercise. This would have been an irresponsible standpoint in view of the fact that much of the evidence presented in the report could be construed as inconclusive. The researchers, to a large extent, focused on prevalent perceptions in the public realm; this was merely contextualised in a larger report format. However, in an assessment of the period until June 2008, there is enough evidence in the report to warrant concern.

There are growing fears that local water pollution is on the increase. Apart from industrial pollution, there have been shocks such as faecal pollution - especially further upstream. The objective of local government should be to ensure that states of shock do not become long-term trends. In certain cases this has arguably already happened, and where possible, such shocks should be avoided in the future. The effects of pollution on local livelihoods may be compounded by the actual and perceived poor quality of drinking water in the area. The proper maintenance and management of water infrastructure can go some way towards stemming the tide of civil discontent. In particular, the potable water treatment 
operations of the local authority should be above suspicion.

According to data collected during fieldwork, civil society has a notable distrust of local government institutions. The research team came to the conclusion that there was a dire need for better communication between local government and civil society on the issue of water. The report also suggested that a local water forum be created. ${ }^{91}$ This would ideally be an opportunity for stakeholders to discuss water-related problems in an open and transparent manner. By establishing firm lines of communication, local government will be in a better position to move towards building a working relationship of mutual trust and cooperation with all interested parties, which would in turn help to maintain and promote current livelihood strategies.

We also recommend that a concerted effort be made to reduce all pollution levels in the Vaal River. If effective safety measures cannot be introduced to protect the environment and human society, alternative arrangements should be made to provide Parys with potable water. Potential strategies would be, for example, to make a renewed effort to secure the services of Rand Water as a bulk water provider. Alternatively a direct pipeline should be laid from the Vaal Dam to transport water to Parys and Vredefort. Furthermore, development of additional industries upstream should be carefully monitored.

91 A Ngwathe sub-catchment forum, was established in February 2009. Several meetings of the executive committee of the forum have taken place since April 2009. A public forum meeting is scheduled for the end of July 2009. 